\title{
Chlamydia A in the female genital tract
}

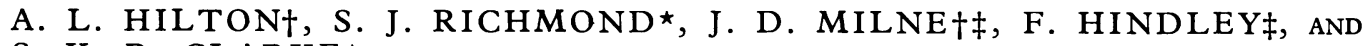 \\ S. K. R. CLARKE* \\ From the Departments of Venereology†, Bristol Royal Infirmary, and the Royal United Hospital, Bath, the \\ Public Health Laboratory ${ }^{\star}$, Bristol, and the Family Planning Association Clinic $\neq$, Bristol Royal Infirmary
}

The first genital tract isolates of Chlamydia A were obtained from parents of babies suffering from TRIC ophthalmia neonatorum, by growth in the yolk sac of fertile eggs (Jones, Collier, and Smith, 1959; Jones, Al-Hussaini, and Dunlop, 1964). It was noted that the fathers of these babies were frequently suffering from non-gonococcal urethritis (NGU) and that the mothers often showed changes in the cervix. The isolation of Chlamydia from two of nine unselected males suffering from NGU confirmed the association of these organisms with non-specific genital infection (Dunlop, Al-Hussaini, Garland, Treharne, Harper, and Jones, 1965).

These early observations have been confirmed and extended since the development of irradiated McCoy cell cultures for the isolation of Chlamydia A. With this technique, it has been established that Chlamydia can be isolated from the urethra of about 40 per cent. of men with NGU (Dunlop, Vaughan-Jackson, Darougar, and Jones, 1972; Oriel, Reeve, Powis, Miller, and Nicol, 1972; Richmond, Hilton, and Clarke, 1972) and that they are only rarely isolated from equally promiscuous men without urethritis (Oriel and others, 1972; Richmond and others, 1972).

However, a similar isolation rate was shown in men suffering from gonorrhoea (G) (Richmond and others, 1972) which threw doubt on whether a chlamydial infection was the initial cause of NGU, and raised the possibility that urethritis of any cause activated an existing but quiescent chlamydial infection in the male urethra. This activated infection appeared to be pathogenic since Chlamydia-positive patients with $\mathrm{G}$ were much more prone to develop post-gonococcal urethritis (PGU) than Chlamydia-negative G patients, and since the isolation rate of Chlamydia in men with NGU who had a long-standing untreated urethral

Received for publication July 26,

Presented at the Spring Meeting of the M.S.S.V.D. at Brussels in May, 1973

Address for reprints: Dr A. L. Hilton, Bristol Royal Infirmary, Bristol, BS2 8HW discharge was greater than the isolation rate in men who came for treatment early.

The present study was designed to investigate Chlamydia in the female genital tract in promiscuous populations. The aims were:

(1) To compare the Chlamydia isolation rate in women attending venereal disease (VD) clinics with the rate in a control group of sexually active non-promiscuous women to determine whether Chlamydia are sexually-transmitted organisms;

(2) To correlate the finding of Chlamydia with that of gonococci, Trichomonas vaginalis (TV), Candida albicans, and herpes simplex virus type 2 (HSV 2) to see whether concomitant infection with these recognized pathogens affects the Chlamydia isolation rate;

(3) To determine whether factors that influence the hormonal status of the patient (oral contraception, pregnancy, and the stage in the menstrual cycle) affect the Chlamydia isolation rate;

(4) To investigate the Chlamydia isolation rate in women who were known consorts of men suffering from NGU and to compare this with the rate in women whose consorts were not suffering from urethritis;

(5) To discover whether chlamydial infection in the absence of other recognized pathogens was associated with particular symptoms, or with macroscopic changes in the cervix.

\section{Patients and methods}

\section{PATIENTS}

The study was carried out on female patients attending the VD clinics at the Bristol Royal Infirmary, the Central Health Clinic, Bristol, and the Royal United Hospital, Bath, between August 14, 1972, and March 1, 1973. Patients were accepted who had not been treated with antibiotics, sulphonamides, or metronidazole in the preceding 2 months; two cases were included in which recent cotrimoxazole and metronidazole had not affected the isolation of Chlamydia. The VD clinic patients attended either because they admitted possible exposure to sexually- 
transmitted infections, or because they were referred for exclusion of these infections by consorts, their family physicians, or other clinics. A group of pregnant, unmarried women was referred to a special VD clinic for screening. All the patients were seen by one physician (A.L.H.) and they were classified in two ways: firstly according to whether or not other infections (G, TV, HSV 2, or Candida) were present; secondly, according to the diagnosis made in the case of the partner:

(A) G consorts;

(B) NGU consorts;

(C) Presumptive G or NGU consorts;

(D) No known urethritis in male partner.

It was not possible to make a precise diagnosis in the third group in which some male contacts had a history of discharge which had cleared spontaneously or after treatment elsewhere, while in others the culture was non-confirmatory or (in the case of four men) not done. Hence the female patients in this vague group were classified as 'presumptive G or NGU consorts'.

There was thus a certain or partial knowledge of the diagnosis of the male partners in groups $\mathrm{A}, \mathrm{B}$, and $\mathrm{C}$, and the remainder were classed together, by exclusion, in group D. The great majority of the male partners of the women in this last group had not been examined.

\section{Control group}

Patients attending the Family Planning Association (FPA) Clinic at the Bristol Royal Infirmary between December 14, 1972, and March 1, 1973, were used as control subjects. They were selected and examined by two clinicians (J.D.M. and F.H.). Only patients who stated that they had a single consort, where the relationship appeared stable, were included.

\section{COLLECTION OF SPECIMENS AND CULTURE TECHNIQUES}

\section{VD Clinic Patients}

\section{(a) Gonorrhoea}

Routine urethral and cervical smears, and cultures on 'chocolate' agar and trimethoprim-vancomycin-nystatin agar were invariably carried out. Only those women were included in whom gonococci were cultured, or who had a positive smear together with a positive culture from the male contact.

\section{(b) Trichomonas vaginalis}

TV was diagnosed by vaginal smear (examined by darkground microscopy) and in most cases also by culture in modified Stenton's medium (Stenton, 1957).

\section{(c) Candida albicans}

Candidiasis was diagnosed by smear and in most cases by culture on the 'chocolate' agar used for the isolation of gonococci, and was confirmed by germ tube formation. (d) Chlamydia

Specimens for Chlamydia isolation were obtained by introducing a plain cotton-wool swab into the endocervix and rotating it several times. It was then placed in sorbitol transport medium and kept at $4^{\circ} \mathrm{C}$. until it was transported to the laboratory for isolation of Chlamydia in irradiated McCoy cell cultures by the method previously described (Richmond and others, 1972; Richmond, 1973). Only two preparations were grossly contaminated and were excluded from the series.

\section{(e) Herpes simplex virus type 2}

About $0.5 \mathrm{ml}$. of each specimen used for Chlamydia isolation was inoculated into human embryo fibroblasts when available, or into Bristol HeLa cells, for the isolation of HSV 2 by standard techniques. Preliminary experiments had shown that the sorbitol transport medium was as efficient as the milk-saline transport medium routinely used for the isolation of HSV 2 and that there was no decline in the titre of the virus when kept for 24 hours at $4^{\circ} \mathrm{C}$. Cultures for HSV 2 were obtained from all but twenty of the VD clinic patients.

\section{FPA Clinic Patients}

Specimens were collected from the FPA clinic patients in the same way and cultures for G, TV, Candida, HSV 2, and Chlamydia were obtained from all patients. There was no more delay in transporting the FPA clinic specimens than for the VD clinic specimens. All cultural investigations were carried out at the Bristol Public Health Laboratory.

\section{Results}

279 patients from the VD clinics were examined, of whom about 70 per cent. presented primarily for screening tests, while the remainder presented primarily because of symptoms. 63 patients, all attending for contraceptive advice, were examined at the FPA clinic. Satisfactory McCoy cell preparations were obtained in all these cases; some were slightly contaminated by yeasts and a few specimens were set up twice before a good preparation was obtained.

\section{SEXUAL TRANSMISSION OF CHLAMYDIA}

Table I shows the number of cases in which Chlamydia and other organisms were found in the two groups. $G$ was diagnosed in 20 per cent. of the VD clinic patients, TV in 15 per cent., and Candida in 16 per cent., and HSV 2 was isolated from 3 per cent. These results include 22 patients who were found to have mixed infections of $\mathrm{G}$ and/or TV, Candida, and HSV 2. In the FPA patients there was no G, TV, or HSV 2 infection, and Candida was isolated from 11 per cent. Table II shows that sexually-transmitted organisms were isolated in appreciable numbers from the VD clinic patients who presented primarily for 
TABLE I Organisms found in VD clinic patients and FPA patients

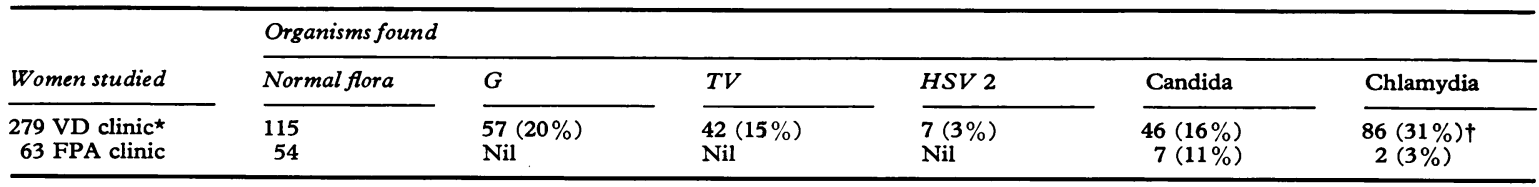

* Includes 22 patients with mixed infections of G and/or TV, Candida, HSV 2.

$\dagger 52$ Chlamydia-positive patients had other infections as well (see Table V).

TABLE II VD clinic patients: Organisms related to primary reason for attendance

\begin{tabular}{|c|c|c|c|c|c|c|}
\hline$V D$ clinic females & Organisms for & & & & & \\
\hline Reason for attendance & Normal flora & $G$ & $T V$ & HSV 2 & Candida & Chlamydia \\
\hline $\begin{array}{l}\text { Screening (197) } \\
\text { Symptoms (82) }\end{array}$ & $\begin{array}{l}85 \\
30\end{array}$ & $\begin{array}{c}53(27 \%) \\
4(5 \%)\end{array}$ & $\begin{array}{l}21(11 \%) \\
21(26 \%)\end{array}$ & $\begin{array}{l}1(0.5 \%) \\
6(7 \%)\end{array}$ & $\begin{array}{l}26(13 \%) \\
20(24 \%)\end{array}$ & $\begin{array}{l}68(35 \%) \\
18(22 \%)\end{array}$ \\
\hline
\end{tabular}

screening. Therefore, differences in promiscuity, rather than in frequency of symptoms probably account for the absence of sexually-transmitted infections in the FPA clinic patients.

The age distribution of the two groups is shown in Table III. The mean age of the VD clinic patients was lower, though the overall age distribution was greater, than in the FPA clinic subjects. The majority of VD clinic patients were single or separated, whereas 71 per cent. of FPA subjects were married (Table IV).

The higher incidence of sexually-transmitted diseases suggests that the VD clinic patients were more promiscuous than the FPA group. The high Chlamydia isolation rate of 31 per cent. in the VD clinic group compared with the 3 per cent. isolation rate in the FPA group (Table I) indicates that Chlamydia is sexually-transmitted, and not part of the normal flora of the genital tract in sexually active women.

\section{EFFECT OF OTHER ORGANISMS ON THE CHLAMYDIA ISOLATION RATE}

Table V compares the Chlamydia isolation rate in VD clinic patients in whom no pathogens were found with the rate in patients concurrently infected with G, TV, Candida, or HSV 2. To elucidate the effect of each of these infections, mixed infections are included as a separate category. Chlamydia was isolated from 23 per cent. of patients in the absence of other infections and this does not differ significantly from the isolation rate in patients with Candida (17 per cent.) or with TV (24 per cent.). There were insufficient HSV 2 infections to allow us to demonstrate

TABLE III Age distribution in VD and FPA clinic patients (Numbers of Chlamydia-positive patients in brackets)

\begin{tabular}{|c|c|c|c|c|c|c|c|}
\hline Women studied & Total No. & \multicolumn{6}{|c|}{ Age (yrs) } \\
\hline $\begin{array}{l}\text { VD clinic } \\
\text { FPA clinic }\end{array}$ & $\begin{array}{r}279(86) \\
63(2)\end{array}$ & $\begin{array}{l}3 \\
0\end{array}$ & $\begin{array}{c}92 \\
2\end{array}$ & $\begin{array}{r}109 \\
32(37)\end{array}$ & $\begin{array}{l}39(15) \\
20\end{array}$ & $\begin{array}{c}36(10) \\
9\end{array}$ & $\begin{array}{l}22 \cdot 8(23 \cdot 3) \\
25 \cdot 5\end{array}$ \\
\hline
\end{tabular}

TABLE IV Marital status of VD and FPA clinic patients (Numbers of Chlamydia-positive patients in brackets)

\begin{tabular}{|c|c|c|c|c|}
\hline Women studied & Total & \multicolumn{3}{|c|}{ Marital status } \\
\hline $\begin{array}{l}\text { VD clinic } \\
\text { FPA clinic }\end{array}$ & $\begin{array}{r}279(86) \\
63(2)\end{array}$ & $\begin{array}{rr}190(56) \\
18 \quad(2)\end{array}$ & $\begin{array}{l}50(16) \\
45\end{array}$ & $\begin{array}{c}39(14) \\
0\end{array}$ \\
\hline
\end{tabular}

TABLE V VD clinic patients: Effect of other organisms on Chlamydia isolation rate

\begin{tabular}{|c|c|c|c|c|c|c|c|}
\hline$V D$ clinic females & Normal flora ${ }^{\star}$ & Candida & $T V$ & $G$ & $H S V 2$ & $\begin{array}{l}\text { Mixed } \\
\text { infections }\end{array}$ & Total \\
\hline $\begin{array}{l}\text { Total } \\
\text { Chlamydia-positive }\end{array}$ & $\begin{array}{l}149 \\
34(23 \%)\end{array}$ & $\begin{array}{l}40 \\
7(17 \%)\end{array}$ & $\begin{array}{l}25 \\
6(24 \%)\end{array}$ & $\begin{array}{l}40 \\
25(62 \%)\end{array}$ & $\begin{array}{l}3 \\
1\end{array}$ & $\begin{array}{l}22 \\
13(59 \%)\end{array}$ & $\begin{array}{l}279 \\
86(31 \%)\end{array}$ \\
\hline
\end{tabular}

* Those with Chlamydia not excluded as in Tables I and II. 
whether this virus has any effect on the Chlamydia isolation rate. Patients with $G$ had a significantly higher isolation rate (62 per cent.; $P<0.001)$ than the other patients, and the high rate in the "mixed infection" category (59 per cent.) was due to the fact that this group included seventeen patients with $G$, eleven of whom also had Chlamydia. The overall Chlamydia isolation rate in patients with $\mathrm{G}$ was therefore 63 per cent. (36 out of 57).

This difference in isolation rate between patients with and without $G$ cannot be accounted for simply on the basis of the greater promiscuity of the women with G. When the patients were categorized on the basis of their recent sex histories, and when patients with and without $G$ within the same category were compared (Table VI), a similar difference in Chlamydia isolation rate was demonstrated within each category. In other words, the high rate was related specifically to the infection with $G$, not just dependent on the extent to which these patients had been exposed to the risk of infection. Table VI also demonstrates that the Chlamydia isolation rate does not differ appreciably in these different promiscuity categories, wheras $G$, as would be expected, is commoner in those who admit exposure to the risk of infection in the 3 months before attendance. It appears, therefore, tha an assessment of promiscuity simply on the basis of recent sex contacts is inadequate with infections by Chlamydia, which, although sexually-transmitted, may cause prolonged rather than acute infections

CHLAMYDIA ISOLATIONS RELATED TO URETHRITIS IN THE MALE

Table VII shows the Chlamydia isolations in the VD clinic women grouped according to whether or not their male partners had urethritis. The $G$ consort group, in whom the Chlamydia isolation rate was 62 per cent., was made up mainly of women who themselves had G, but it included eight cases in which $G$ was cultured from the male but not from his female consort. Chlamydia was isolated from 34 per cent. of definite NGU consorts, from 27 per cent. of presumptive urethritis consorts, and from 17 per cent. of women who had apparently had no contact with a man with urethritis. The difference between the Chlamydia isolation rate in definite NGU consorts and in patients whose male partners had no urethritis is significant at the 2 per cent. level.

The case cards of the 26 Chlamydia-positive women whose consorts were not known to have had urethritis, of whom 23 received no treatment initially, were examined between 3 and 8 months after their first attendance to discover whether any patient had been asked to return by an infected consort. Retrospectively, one patient was discovered to have been a contact of a man with $\mathrm{G}$, before her initial visit. None of the remaining 25 patients or their male partners attended the VD clinics again, which suggests the male partners of these Chlamydia-positive women did not develop NGU. There was, however, no way of discovering whether any of these patients had subsequently received treatment elsewhere, or had left the area.

Follow-ups on the 124 Chlamydia-negative women whose consorts were not known to have had urethritis were not attempted, so we do not know whether any of their consorts subsequently developed NGU.

\section{CLINICAL FINDINGS}

(a) Symptoms, amount of vaginal discharge, and macroscopic appearance of the cervix

Table VIII shows the symptoms (elicited by direct

TABLE VI Sex contacts of VD clinic patients within last 3 months

\begin{tabular}{|c|c|c|c|c|c|c|c|}
\hline \multirow[b]{2}{*}{$V D$ clinic females } & \multicolumn{7}{|c|}{ Sexual contacts } \\
\hline & Virgin & $\begin{array}{l}\text { No sexual } \\
\text { intercourse } \\
\text { in last } 3 \text { mths }\end{array}$ & $\begin{array}{l}\text { Marital } \\
\text { only }\end{array}$ & $\begin{array}{l}\text { Regular } \\
\text { partner only }\end{array}$ & $\begin{array}{l}\text { Marital and } \\
\text { casual(s) }\end{array}$ & Casual(s) & Total \\
\hline $\begin{array}{l}\text { Total with } \mathrm{G} \\
\text { Chlamydia-positive with } \mathrm{G}\end{array}$ & $\begin{array}{l}0 \\
0\end{array}$ & $\begin{array}{l}0 \\
0\end{array}$ & $\begin{array}{l}8 \\
5\end{array}$ & $\begin{array}{l}20 \\
15(75 \%)\end{array}$ & $\begin{array}{l}6 \\
3\end{array}$ & $\begin{array}{l}23 \\
13(57 \%)\end{array}$ & $\begin{array}{l}57 \\
36(63 \%)\end{array}$ \\
\hline $\begin{array}{l}\text { Total without } \mathrm{G} \\
\text { Chlamydia-positive with no } \mathrm{G}\end{array}$ & $\begin{array}{l}1 \\
0\end{array}$ & 22 & $\begin{array}{l}28 \\
7(25 \%)\end{array}$ & 104 (19\%) & $\begin{array}{l}8 \\
1\end{array}$ & $\begin{array}{l}59 \\
18(31 \%)\end{array}$ & 222 (23\%) \\
\hline
\end{tabular}

TABLE VII VD clinic patients: Chlamydia isolations related to urethritis in male partner

\begin{tabular}{|c|c|c|c|c|c|}
\hline \multirow[b]{2}{*}{ VD clinic females } & \multicolumn{5}{|c|}{ Urethritis in male partner } \\
\hline & $G$ consorts & NGU consorts & $\begin{array}{l}\text { Presumptive } \\
\text { urethritis } \\
\text { consorts }\end{array}$ & $\begin{array}{l}\text { No contact with } \\
\text { male with known } \\
\text { urethritis }\end{array}$ & Total \\
\hline $\begin{array}{l}\text { Total } \\
\text { Chlamydia-positive }\end{array}$ & $\begin{array}{l}65 \\
40(62 \%)\end{array}$ & $\begin{array}{l}38 \\
13(34 \%)\end{array}$ & $\begin{array}{l}26 \\
7(27 \%)\end{array}$ & $\begin{array}{l}150 \\
26(17 \%)\end{array}$ & $\begin{array}{l}279 \\
86(31 \%)\end{array}$ \\
\hline
\end{tabular}


TABLE VIII Effect of Chlamydia on the symptoms, amount of vaginal discharge, and macroscopic appearance of cervix

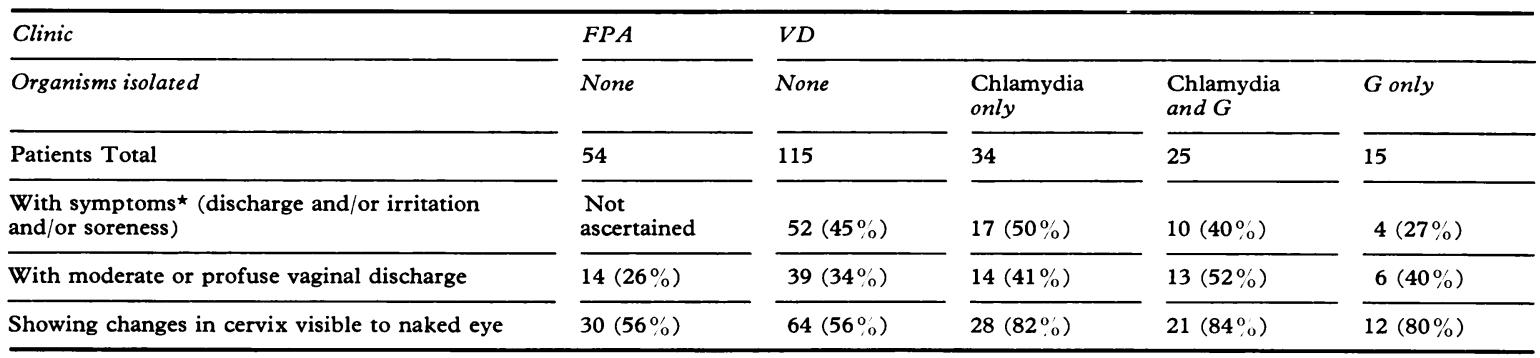

* Elicited by direct questioning.

questioning), the amount of vaginal discharge, and the appearance of the cervix to the naked eye in various groups of patients. Those from whom no organisms were isolated were compared with those from whom only Chlamydia was isolated; $\mathrm{G}$ patients with and without Chlamydia were compared in the same way. The cervices which were either 'eroded', 'infected', or both 'eroded and infected', were grouped together as showing changes, since it is so often difficult to distinguish accurately between these different categories (Coppleson, Reid, and Pixley, 1967). Table VIII shows there was little difference between the patients with and without Chlamydia as regards symptoms and amount of vaginal discharge and, moreover, that Chlamydia did not significantly alter the symptoms and amount of vaginal discharge in patients with G. However, there was a difference in the number of patients showing cervical changes; about 80 per cent. of patients with Chlamydia only, with G, and with Chlamydia and G, showed changes, compared with 56 per cent. of patients, from both FPA and VD clinics, with no infection present. So Chlamydia does not increase the incidence of changes visible to the naked eye in patients with $G$, though it does appear to be associated with an increase in the incidence of cervical change when compared with the patients who were not infected with either $G$ or Chlamydia $(\mathbf{P}<0.01)$.

(b) Cystitis

22 VD clinic women had symptoms of dysuria with or without an increase in frequency of micturition at the time of examination, and 63 gave a past history of ' cystitis'. The Chlamydia isolation rate in these patients did not differ from the overall isolation rate. There did not therefore appear to be any association between Chlamydia and the symptoms of cystitis in these women.

\section{(c) Salpingitis}

One VD clinic patient was considered to have prolonged pelvic infection; she was Chlamydia-positive.

\section{HORMONAL INFLUENCES}

\section{(a) Pregnancy}

37 of the VD clinic patients were pregnant (of whom 27 were unmarried women referred specifically for screening), nine were infected with Candida, three with $G$, one with $T V$, and one was 'a presumptive NGU consort'. Chlamydia were isolated from seven patients (19 per cent.).

When the three women with $G$ and the consort of NGU were excluded (since these conditions have already been shown to influence the incidence of Chlamydia isolations), it was found that all the Chlamydia-positive patients were in their last trimester, whereas over half the Chlamydia-negative patients were in their first or second trimesters (Table IX). The numbers are small, but they suggest that the stage of pregnancy may influence the Chlamydia isolation rate.

TABLE IX Pregnancy: Chlamydia isolations related to stage in pregnancy ${ }^{\star}$

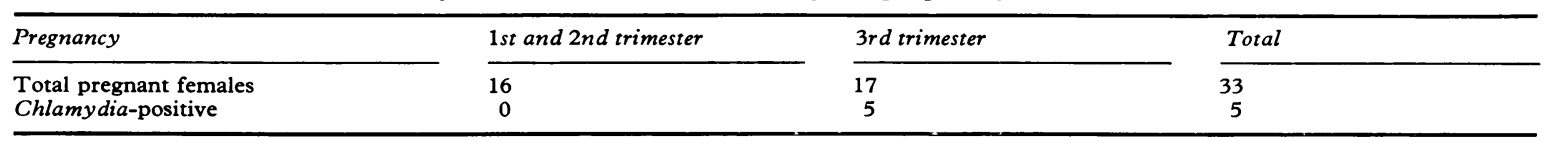

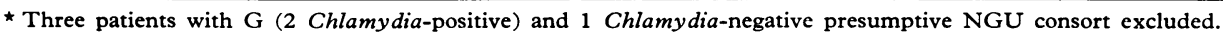


(b) Oral contraceptives

92 of the 279 VD clinic patients were using oral contraceptives at the time of examination, and the Chlamydia isolation rate of 45 per cent. in those on oral contraceptives was found to be significantly higher than the rate of 24 per cent. in those not taking them (Table X; P $<0.001$ ). This effect was also seen when the patients were divided into their various subgroups, particularly in the women with no G (36 per cent. compared with 16 per cent.; $P<0.001$ ) and the NGU consorts (57 per cent. compared with 21 per cent. ; $P<0.05$ ). It was shown least in the women with $G$, the group found to have the highest Chlamydia isolation rate (Table $\mathrm{X}$ ).

The proportion of patients on 'the pill' was approximately the same (about 33 per cent.) in each subgroup, so that the increased rate appears to be a genuine effect of 'the pill' itself and not due to a greater number of patients on oral contraceptives in the groups in which the isolation rate was high (that is, the women with G and the NGU consorts). When these patients were classified according to the history of their sexual contacts, they did not appear to be appreciably more promiscuous than the rest of the VD clinic patients.

\section{(c.) Stage of Menstrual Cycle}

To see whether the stage in the menstrual cycle had any effect on the isolation of Chlamydia, patients were divided according to the number of weeks that had elapsed since the first day of their last menstrual period at the time of presentation at the clinic. 49 per cent. of patients presented in the second or third week, 25 per cent. in the first or fourth week, and 13 per cent. were pregnant. The remaining 13 per cent. of patients with a cycle of more than 28 days included young girls at puberty, patients approaching the menopause, and patients with a long cycle, some of whom may possibly have been in early pregnancy. Since these were a hormonally heterogeneous group, only patients presenting within 28 days of their last menstrual period have been included in Table XI. This shows a Chlamydia isolation rate of 42 per cent. in patients presenting in weeks 1 and 4, which was

TABLE X VD clinic patients: Effect of oral contraception on Chlamydia isolations

\begin{tabular}{|c|c|c|c|c|c|c|c|}
\hline \multicolumn{3}{|l|}{ Females } & \multirow{2}{*}{$\begin{array}{l}\text { Total } \\
279\end{array}$} & \multirow{2}{*}{$\begin{array}{l}\text { With G } \\
57\end{array}$} & \multirow{2}{*}{$\begin{array}{l}\text { Without } G \\
222\end{array}$} & \multirow{2}{*}{$\begin{array}{l}\text { Consorts of men } \\
\text { with NGU }\end{array}$} & \multirow{2}{*}{$\begin{array}{l}\begin{array}{l}\text { No known } \\
\text { urethritis in } \\
\text { male partner }\end{array} \\
150\end{array}$} \\
\hline & & & & & & & \\
\hline \multirow[t]{2}{*}{$\begin{array}{l}\text { Oral } \\
\text { contraceptives }\end{array}$} & $\begin{array}{l}\text { Not } \\
\text { used }\end{array}$ & $\begin{array}{l}\text { Total females } \\
\text { Chlamydia positive }\end{array}$ & $\begin{array}{l}92 \\
41(45 \%)\end{array}$ & $\begin{array}{l}20 \\
15(75 \%)\end{array}$ & $\begin{array}{l}72 \\
26(36 \%)\end{array}$ & $\begin{array}{l}14 \\
8(57 \%)\end{array}$ & $\begin{array}{l}44 \\
11(25 \%)\end{array}$ \\
\hline & Used & $\begin{array}{l}\text { Total females } \\
\text { Chlamydia positive }\end{array}$ & ${ }_{45}^{187}(24 \%)$ & $\begin{array}{l}37 \\
21(57 \%)\end{array}$ & $\begin{array}{l}150 \\
24(16 \%)\end{array}$ & $\stackrel{24}{5(21 \%)}$ & ${ }_{15}^{106}(14 \%)$ \\
\hline \multicolumn{3}{|c|}{ Significance of difference } & $\begin{array}{l}\chi^{2}=12 \cdot 15 \\
P<0.001\end{array}$ & $\begin{array}{l}\chi^{2}=1.85 \\
0.2>P>0.1\end{array}$ & $\begin{array}{l}\chi^{2}=11 \\
P<0.001\end{array}$ & $\begin{array}{l}\chi^{2}=5.17 \\
P<0.05\end{array}$ & $\begin{array}{l}\chi^{2}=2.55 \\
0.2>P>0.1\end{array}$ \\
\hline \multicolumn{3}{|c|}{ Percentage of patients using oral contraception } & 33 & 35 & 32 & 37 & 29 \\
\hline
\end{tabular}

TABLE XI VD clinic patients: Chlamydia isolations related to stage of menstrual cycle and oral contraception

\begin{tabular}{|c|c|c|c|c|c|c|}
\hline \multirow{2}{*}{\multicolumn{2}{|c|}{ VD clinic females }} & & \multicolumn{4}{|c|}{ Stage in menstrual cycle } \\
\hline & & & Week 2 & \multirow{2}{*}{$\begin{array}{l}\text { Week } 3 \\
70 \\
20 \\
29\end{array}$} & Week 4 & \multirow{2}{*}{$\begin{array}{l}\text { Week } 1 \\
41 \\
15 \\
37\end{array}$} \\
\hline All females & & $\begin{array}{l}\text { Total } \\
\text { Chamydia-positive } \\
\text { Chlamydia isolation rate (per cent.) }\end{array}$ & $\begin{array}{l}66 \\
18 \\
27\end{array}$ & & $\begin{array}{l}30 \\
15 \\
50\end{array}$ & \\
\hline & & & & & & \\
\hline \multirow[t]{4}{*}{$\begin{array}{l}\text { Oral } \\
\text { contraceptives }\end{array}$} & Used & $\begin{array}{l}\text { Total females } \\
\text { Chlamydia-positive } \\
\text { Chlamydia isolation rate (per cent.) }\end{array}$ & $\begin{array}{r}27 \\
8 \\
30\end{array}$ & $\begin{array}{r}23 \\
9 \\
39\end{array}$ & $\begin{array}{l}18 \\
11 \\
61\end{array}$ & $\begin{array}{r}17 \\
9 \\
53\end{array}$ \\
\hline & & & & & & \\
\hline & $\begin{array}{l}\text { Not } \\
\text { used }\end{array}$ & $\begin{array}{l}\text { Total females } \\
\text { Chlamydia-positive } \\
\text { Chlamydia isolation rate (per cent.) }\end{array}$ & $\begin{array}{l}39 \\
10 \\
26\end{array}$ & $\begin{array}{l}47 \\
11 \\
23\end{array}$ & $\begin{array}{r}12 \\
4 \\
33\end{array}$ & $\begin{array}{r}24 \\
6 \\
25\end{array}$ \\
\hline & & & & & & \\
\hline
\end{tabular}


significantly higher than the rate of 28 per cent. found in patients presenting in weeks 2 and $3(P<0.05)$. This effect was seen only in the patients on oral contraceptives; the isolation rate in patients not using oral contraception was similar throughout the 4-week period. This suggests that the effect of the oral contraceptive regime on the isolation of Chlamydia was greatest during the time the contraceptive was withheld.

\section{INCLUSION-FORMING UNITS}

To obtain an idea of the amount of Chlamydia in the secretions tested, an estimate of the number of inclusion-forming units (IFU) per $0.25 \mathrm{ml}$. of clinical specimen was made when a specimen was positive (Richmond and others, 1972). The range in number of IFU was again found to be very wide (Table XII), but the distribution of IFU in the various diagnostic categories did not differ from the overall distribution of IFU. However, a significantly higher proportion of the positive specimens from patients on oral contraceptives had more than 100 IFU in their initial pass coverslip than the positive specimens from patients not using them (Table XII $; \mathbf{P}<0.01$ ). This method of estimating infectivity is obviously a very crude one, but it does suggest that oral contraceptives may increase the amount of infective material in the secretions, as well as the Chlamydia isolation rate.

Altogether, 26 of the 86 positive specimens ( 30 per cent.) had less than ten inclusions in the initial pass coverslip, which means that the Chlamydia isolation rate would vary considerably if the sensitivity of the cell culture system varied by as much as $1 \log _{10}$.

\section{Discussion}

The difference between Chlamydia isolations in the promiscuous and the non-promiscuous female populations (Table I) is good evidence that Chlamydia is sexually-transmitted. The isolation rate of 31 per cent. in the VD clinic patients indicates how common an infection this is in this group.

A large proportion of these infections were found in women who also had G (Table V). The chlamydial infection in these patients with $G$ did not seem to contribute to their symptoms or to produce signs visible to the naked eye on examination of the cervix; almost all of these women had attended the clinic primarily for screening, rather than with complaints of particular symptoms.

Chlamydia was found previously in 32 per cent. of men with G (Richmond and others, 1972), so the 63 per cent. isolation rate found in women with $G$ in the present study cannot be explained simply by postulating that the infection had been caught from the male consort. It was suggested (Richmond and others, 1972) that a $G$ infection in the male may reactivate a chlamydial infection which was present but quiescent in the male urethra. The same situation may be occurring in the cervix and, since Chlamydia was recovered from 63 per cent. of women with G, the proportion of those infected in a group of promiscuous women may be higher than in a similar male population, for with similar techniques a Chlamydia isolation rate above about 40 per cent. has not yet been demonstrated in men (Dunlop and others, 1972; Oriel and others, 1972; Richmond and others, 1972).

Chlamydia may survive better in the cervix than in the male urethra. If so, then infection diagnosed serologically would be commoner in promiscuous women than in similarly promiscuous men, but no evidence is yet available to decide this issue. It was noted, however, that in men a severe gonococcal urethritis with a profuse discharge was associated with a significantly reduced Chlamydia isolation rate (Richmond and others, 1972), and it is possible that the less severe gonococcal infection in the cervix may provide more favourable conditions for the growth of Chlamydia.

Pigeons and poultry with clinical manifestations of Chlamydia B infections have been shown to be concomitantly infected with bacteria such as Salmonella and Pasteurella, and these bacterial infections may enhance the severity of the chlamydial infection in these species (Stortz, 1971); it has been suggested that, in individuals with chronic trachoma, bacterial conjunctivitis causes a clinical exacerbation of the disease, producing signs of active trachoma (Wood and Dawson, 1967). The present study has produced evidence that $G$ in the female genital tract is associated with an increased incidence of chlamydial infection in a promiscuous group. $G$ is therefore

TABLE XII VD clinic patients: Number of inclusion-forming units (IFU) in Chlamydia-positive specimens

\begin{tabular}{|c|c|c|c|c|c|}
\hline Positive specimens & & \multicolumn{4}{|c|}{ IFU per $0.25 \mathrm{ml}$. clinical specimen } \\
\hline Total & 86 & 26 & 17 & 26 & 17 \\
\hline $\begin{array}{l}\text { From patients not using oral } \\
\text { contraceptives } \\
\text { From patients using oral contraceptives }\end{array}$ & $\begin{array}{l}45 \\
41\end{array}$ & $\begin{array}{l}16 \\
10\end{array}$ & $\begin{array}{r}14 \\
3\end{array}$ & $\begin{array}{r}8 \\
18\end{array}$ & $\begin{array}{r}7 \\
10\end{array}$ \\
\hline
\end{tabular}


important in the maintenance of chlamydial infections in such groups.

Up to the present, it has been impossible to define the incubation period for genital chlamydial infection. Oriel and others (1972) tried to assess the incubation period in Chlamydia-positive NGU patients on the assumption that Chlamydia was the primary cause of their urethritis. They found the incubation period varied from 1 to 42 days, as it did in the Chlamydianegative NGU patients, with no 'peak period' as can be demonstrated in an acute infection such as gonococcal urethritis (Boyd, Csonka, and Oates, 1958). An incubation period was impossible to assess in women since the infection does not produce a clinical syndrome recognizable by our methods of examination (Table VIII). In the present study Chlamydia was isolated from four women who denied having had sexual intercourse within the last 3 months (Table VI). All the evidence suggests that a chlamydial infection is not limited to an acute episode but occurs as a persistent type of infection in the male and female genital tract.

Oral contraception was associated with an increased Chlamydia isolation rate (Table $\mathrm{X}$ ), particularly during weeks 1 and 4 of the cycle (Table XI). It is impossible to explain this effect if Chlamydia isolations always coincide with the primary chlamydial infection. Those on oral contraceptives appeared to be a fair sample of the VD clinic patients as a whole, not biased in favour of the groups from which Chlamydia was most frequently isolated or found only amongst the patients who, from their recent sex contacts, appeared to be the most promiscuous. It is possible that hormonal alteration may activate a latent infection in the cervix, not detectable by cell culture. Moreover, this effect was seen least in the women with $\mathrm{G}$ where the infection by Chlamydia may already have been activated by the gonorrhoea infection. The possible effect of oral contraceptives in activating latent chlamydial infection was thus much more obvious in patients free from $G$, in itself a potent activator. The stage of pregnancy may also influence the isolation rate of Chlamydia. This may be a hormonally mediated effect, though a larger number of pregnant patients would have to be studied to decide this issue.

Chlamydia was isolated from 13 of 38 (34 per cent.) of consorts of men with NGU (Table VII). They could have caught this infection from their male partners, since 40 per cent. of men with NGU have demonstrable chlamydial infections. The female consorts of Chlamydia-positive NGU patients are themselves frequently Chlamydia-positive (Dunlop and others, 1972; Oriel and others, 1972). This is further evidence of the sexually-transmissible nature of Chlamydia, but does not resolve the question which partner transmitted the infection to the other.

If the isolation of Chlamydia in cell culture correlates with infectivity, a chlamydial infection in a female must originally have been caught from a male suffering from urethritis, either G or NGU, since the infection is sexually-transmissible; but isolations were made from 25 women who had not been, as far as could be discovered, in contact with a man with urethritis in the recent past. Their infections may, therefore, have been acquired from a previous partner with urethritis, about whom information was not forthcoming, or from a male with asymptomatic urethritis. The lack of any evidence of urethritis in the male consort in the recent history of these women points to the persistence of clinically silent infections by Chlamydia.

Since none of the sexual partners of these 25 Chlamydia-positive women was proven to have developed NGU, it seems that active Chlamydia infection in the female may not regularly predispose to NGU developing soon after in the male. This could be explained by again invoking the latency theory: the male partner may acquire the Chlamydia from his Chlamydia-positive consort, but his infection would be quiescent and become manifest only when he developed a urethritis due to another agent. His activated Chlamydia infection may then cause PGU if he had $G$, or a prolongation of his urethral discharge (if not treated) if he had NGU.

The situation which is emerging is a complicated one. If Chlamydia infection, as detected by isolation in irradiated $\mathrm{McCoy}$ cells, represents only an active phase of a prolonged and often quiescent infection, and some evidence has been presented to suggest that this is so, then it will be necessary to rely on serological evidence to distinguish between the Chlamydiainfected and Chlamydia-free patients. Serological work in men by Reeve, Gerloff, Casper, Philip, Oriel, and Powis, 1974) has demonstrated possible infection by Chlamydia in the absence of concurrent urethritis, and further studies may elucidate the position in women.

The possible effects of hormonal factors, such as oral contraception and pregnancy, in reactivating chlamydial infections requires study. Observations on the appearance of the cervix which were made in this survey, which suggested that Chlamydia may be associated with an increase in the frequency of macroscopic changes, could be extended by use of the colposcope. This should decide whether these common genital infections are associated regularly with characteristic changes that can be seen with the operating microscope, such as the marginal cervical follicles described by Dunlop, Jones, and 
Al-Hussaini (1964) and Dunlop, Freedman, Garland, Harper, Jones, Race, du Toit, and Treharne (1967).

Consideration of these points may help to decide the policy to be adopted in treating NGU consorts and whether the large reservoir of chlamydial infection in the genital tract in promiscuous women should be treated or not.

\section{Summary}

A Chlamydia isolation rate of 31 per cent. was found in a group of 279 women attending venereal disease clinics, compared with an isolation rate of 3 per cent. in 63 women attending a Family Planning Association clinic. The VD clinic women were much more promiscuous and it is concluded that Chlamydia is sexually transmitted.

In the VD clinic group, Chlamydia was isolated from 36 of 57 women (63 per cent.) with gonorrhoea (G), from 13 of 38 (34 per cent.) of consorts of men with non-gonococcal urethritis, and from 26 of 150 (17 per cent.) of women who had apparently had no contact with a male with urethritis. Infections with Candida or Trichomonas vaginalis did not affect the Chlamydia isolation rate.

Hormonal factors may influence the Chlamydia isolation rate, since it was greater in patients using oral contraceptives than in those who did not. This effect, which was highly significant in the patients without $G$ but not in those with $G$, was seen particularly during weeks 1 and 4 of the menstrual cycle.

It is suggested that Chlamydia gives rise to persistent but frequently quiescent infections in the genital tract in promiscuous women and that both gonococcal infection and the use of oral contraceptives may reactivate these infections.

In patients with $G$, Chlamydia did not affect the symptoms or the appearance of the cervix to the naked eye. Of those without $G$, more patients infected with Chlamydia had such changes in the cervix than uninfected patients, although the symptoms and the amount of vaginal discharge were similar.

We are grateful to $\mathrm{Mr} \mathrm{J}$. A. Garrett and his colleagues, Department of Medical Physics, Bristol Royal Infirmary, for irradiating the McCoy cells, and to Dr A. J. Hedges, Department of Bacteriology, University of Bristol, for statistical advice.

We should like to thank Mr E. O. Caul for carrying out the HSV 2 isolation studies, and Mr R. J. Edwards for culturing the specimens from the FPA clinic for gonococci, $T$. vaginalis and $C$. albicans.

We acknowledge a grant from the Department of Health and Social Security for an M.S.E. Super Minor Centrifuge which was used for the Chlamydia isolations.

\section{References}

Boyd, J. T., CsonKA, G. W., and OATES, J. K. (1958) Brit. F. vener. Dis., 34, 40

Coppleson, M., Reid, B., and Pixley, E. (1967) 'Preclinical Carcinoma of the Cervix Uteri', p. 133. Pergamon Press, Oxford

Dunlop, E. M. C., Al-Hussaini, M. K., Garland, J. A., Treharne, J. D., Harper, I. A., and Jones, B. R. (1965) Lancet, 1, 1125

- Freedman, A., Garland, J. A., Harper, I. A., JoNes, B. R., RACE, J. W., DU TOIT, M. S., and Treharne, J. D. (1967) Amer. F. Ophthal., 63, 1073

- Jones, B. R., and AL-Hussaini, M. K. (1964) Brit. f. vener. Dis., 40, 33

- -, Vaughan-Jackson, J. D., Darougar, S., and JONES, B. R. (1972) Ibid., 48, 425

Jones, B. R., Al-Hussaini, M. K., and Dunlop, E. M. C. (1964) Ibid., 40, 19

- Collier, L. H., and Smith, C. H. (1959) Lancet, 1,902

Oriel, J. D., Reeve, P., Powis, P., Miller, A., and Nicol, C. S. (1972) Brit. F. vener. Dis., 48, 429

Reeve, P., Gerloff, R. K., Casper, E., Philip, R. N., ORIEL, J. D., and PowIS, P. A. (1974) Ibid., 50, in press

Richmond, S. J. (1973) f. med. Lab. Tech., 30, in the press.

—, Hilton, A. L., and Clarke, S. K. R. (1972) Brit. f. vener. Dis., 48, 437

Stenton, P. (1957) f. med. Lab. Tech., 14, 228

STORTZ, J. (1971) 'Chlamydia and Chlamydia-induced Diseases', p. 135. Thomas, Springfield, Ill.

Wood, T. R., and Dawson, C. R. (1967) Amer. F. Ophthal., 63, 1298

\section{Chlamydia A dans les voies genitales de la femme}

SOMMAIRE

Des Chlamydia furent trouvés au taux de 31 pour cent dans un groupe de $\mathbf{2 7 9}$ femmes venues consulter dans des cliniques vénéréologiques, ceci contre un taux d'isolement de 3 pour cent chez 63 femmes s'étant présentées à un dispensaire d'une Association de contrôle des naissances. Les femmes des cliniques anti-vénériennes étaient sexuellement bien plus accueillantes et l'on en déduit que les Chlamydia sont transmises par contacts sexuels.

Dans les cliniques vénéréologiques, les Chlamydia furent isolés chez 36 sur 57 femmes (63 pour cent) atteintes de gonococcie (G), chez 13 sur 38 (34 pour cent) des partenaires d'hommes atteints d'urétrite non gonococcique, et chez 26 sur 150 ( 17 pour cent) de femmes qui, apparemment, n'avaient pas eu de contact avec un homme atteint d'urétrite. L'infection par Candida ou par Trichomonas vaginalis n'a pas eu d'influence sur le taux d'isolement des Chlamydia.

Les facteurs hormonaux peuvent influencer le taux d'isolement des Chlamydia puisque celui-ci fut plus élevé chez les malades utilisant des contraceptifs oraux que chez celles qui ne les employaient pas. Cet effet, hautement significatif chez les malades sans G, ne le 
fut pas en cas de G; il fut observé particulièrement pendant la première et la quatrième semaine du cycle menstruel.

On considère que les Chlamydia entraînent des infections persistantes mais souvent latentes des voies génitales chez les femmes faciles et que l'infection gonococcique, aussi bien que l'emploi des contraceptifs oraux, peuvent les réactiver.

Chez les malades atteintes de G, les Chlamydia n'ont pas eu d'influence sur les symptômes ou sur l'aspect du col à l'oeil nu. Chez celles sans $\mathrm{G}$, les malades infectées par les Chlamydia avaient davantage de modifications du col que les malades non infectées, bien que les symptômes et l'abondance de la sécrétion vaginale fussent similaires. 